\title{
Women in Luther's Life and Theology: Scholarship in Recent Years
}

\author{
Laura Kathryn Jurgens \\ Department of Classics and Religion, University of Calgary, 2500 University Drive NW, Calgary, AB T2N 1N4, \\ Canada; lkjurgen@ucalgary.ca; Tel.: +1-(403)-903-2337
}

Received: 30 December 2019; Accepted: 29 January 2020; Published: 31 January 2020

\begin{abstract}
The purpose of this article is to provide a broad but comprehensive review of the current scholarship on Martin Luther and women. Luther's thoughts and actions still play an important role as witnessed by the recent events commemorating the five-hundredth anniversary of the Protestant Reformation. However, after five-hundred years, it is surprising that there continues to be relatively little scholarship on Luther's ideas about women, especially from a feminist perspective. Luther wrote much about women and related topics such as marriage, sexuality, and the family which can be found throughout nearly every type of his works. For example, Luther not only wrote extensively about women throughout his theological works, but also wrote personal correspondence to women. Yet, Luther's theological attitudes towards women and his encounters with women need to be explored further. This review is significant because it highlights the major scholarly works that address Luther and women. This review not only provides a helpful framework for the readers of this Special Issue of Religions, but it also emphasizes the necessity for future scholarship to continue to explore Martin Luther's complex relationship with women in his life and theology.
\end{abstract}

Keywords: Martin Luther; women; theology; history; socio-historical method; literature review

\section{Introduction}

Many images come to mind when thinking of Martin Luther such as monk, professor, priest, theologian, composer, and family man. His portrait as a reformer is likely his most iconic image since he is primarily known as the individual who initiated the Protestant Reformation. As the man who is recognized as having sparked the Reformation, Luther came to symbolize everything that the Protestant Reformation represented. His thoughts and actions permeated throughout European culture and diversified Christianity to a degree that was not seen in hundreds of years (Hendrix 2017). Arguably, not all historians view this division of Christendom as a cultural contribution. ${ }^{1}$ Blame is often placed on Luther for causing various detrimental consequences brought about by the Protestant Reformation movement. However, even scholars who regret Christianity's diversification still acknowledge that Luther's impact has been extensive, especially on religion, culture, and politics. Due to European powers and colonization, the force of the Protestant Reformation spread across continents and continues to be felt by both Protestants and Catholics today. Martin Luther's thoughts and actions still play an important role as witnessed by the recent events commemorating the five-hundredth anniversary of the Protestant Reformation.

After five-hundred years, it is surprising that there continues to be relatively little scholarship on Martin Luther's theological attitudes towards women and his interactions with women, especially from

1 For a negative impact of the Reformation movement on women more generally, see (Roper 2001). 
a feminist perspective. An educated man's ideas about women are one of the easiest subjects to explore because they are more likely to be written down than women's ideas. ${ }^{2}$ This is certainly the case with Luther. He wrote much about women and related topics such as marriage, sexuality, and the family which can be found throughout nearly every type of his works. For example, Luther not only wrote extensively about women throughout his theological works, but also wrote personal correspondence to women. As an individual living a robust life, Luther would have had many social encounters with women. Yet, Luther's theological attitudes towards women and his personal correspondence with women need to be explored further. This literature review emerges from my dissertation research and it focuses on recent scholarship that explores Luther's theology and relationship with women. This review is significant because it highlights the major scholarly works that address Luther and women. The purpose of this review is to provide a concise update on the latest progress that has been made with the scholarship on Martin Luther and women in hopes that it will spark future research.

\section{Literature Review}

In the 1960s and the 1970s, scholars were influenced by the field of social history which experienced a dramatic growth during these years. This period saw the emergence of the social-historical method. This method was established when historians, such Marc Bloch and Lucien Febvre, ambitiously wanted to replace the "old history" with what they saw as a "wider and more human history" which would encompass all human activities (Burke 1992, pp. 14-15). Bloch and Febvre argued that this "wider human history" could be achieved by engaging with other disciples, especially sociology. Fernard Braudel, who was Febvre's successor, believed that "history and sociology should be particularly close, because the practitioners of both disciplines try - or ought to try - to see the human experience as a whole" (Burke 1992, p. 15). Therefore, the social-historical method originated from considering the human experience as a whole and by combining aspects of traditional historical methodology with a strong emphasis on social and cultural influences (Rahikainen and Fellman 2012, p. 5). For example, the methodologies of social history were influenced by Marxist paradigms such as oppression, consciousness, and agency. ${ }^{3}$ In the 1970s, scholars, like Joan Kelly, Gerda Lerner, and Juliet Mitchell, started to use social history in their own works and started examining women's lived experiences of the past. ${ }^{4}$ Scholars, such as Kelly and Lerner, were not only influenced by the new approaches advocated by social history, but also by the second-wave feminist movement beginning in the 1960s and lasting for about two decades. However, when these scholars conducted their research, they found that there were hardly any women at all in historical works. ${ }^{5}$ It was not that women were absent from history, but that history was mainly written by men and about men. These traditional historical studies, written by male historians, like John Roberts, captured the white, middle-class, male experience and presented this experience as universal (Roberts 1976). Such conventional historical studies have been called "Men's History." In the face of such enormous neglect from conventional historians and traditional historical works, scholars, like Kelly and Lerner, attempted to reconstruct the female past (Lerner 1979). It was not the case that women did not engage with history, but that their behaviours or actions were not considered to be "proper" history. Since the 1960s, scholars, like Kelly and Mitchell, argued that women need to be considered legitimate subjects of study and that scholars should examine the "history of women worthies" (Umansky 2000, p. 10). In other words, women needed to be at the forefront when evaluating history and historical events.

In the 1970s, scholars were primarily concerned with correcting the absence of women from history. The question: "How about women?" was central to their approach. For example, Kelly, Lerner, and Mitchell argued that the approaches scholars use to think about history needed to be revised

\footnotetext{
See (Karant-Nunn and Wiesner-Hanks 2003), p. 2.

See (Howell and Prevenier 2001), p. 90-92.

For example, see (Mitchell 1966).

See (Spongberg 2002), p. 7.
} 
to include women's lives and experiences. This was a radical change because it acknowledged the necessity to include women within a masculinist discourse (Spongberg 2002, p. 10). This radical approach was called "Women's History."

As with Kelly, Lerner, and Mitchell, early modern scholars, like Eileen Power, witnessed a lack of historical studies that focused on women in their field, especially in the 1970s (Power 1975). Conventional historians who wrote about the early modern period might mention queens, martyrs, and reformers' wives, but most studies still focused on men. For example, in 1972, Owen Chadwick's work titled The Reformation still focuses on men and their roles in the movement (Chadwick 1972). Studies, such as those by Chadwick, often consider women as passive partners or do not critically investigate women at all. This is not to say that women have been left out of history because of the "evil conspiracies of men in general or male historians," but because history has traditionally been considered and represented in male-centered terms (Lerner 1979, p. 140).

In 1977, Joan Kelly published an influential work where she explored women's roles in Renaissance society (Kelly 1977, pp. 5-16). She asked the question: “Did women have a Renaissance?" With this work, Kelly was especially interested in exploring women's historical experience of the Renaissance by examining attitudes towards female sexuality, ideologies about women, and women's economic, political, and cultural roles. This study challenged the traditional assumption that women's historical experiences were the same as men's experiences by arguing that women experienced history differently than men. She noted that while men's options expanded during the Renaissance period, the same could not be said about women. She argued that while women's "sexual and affective rights" were encouraged during the medieval period, women "experienced a contraction of social and personal options" during the Renaissance (Kelly 1977, pp. 20-22). In this sense, she argued that women did not have a Renaissance because they did not experience a definite break from the medieval past. With this work, Kelly deviated from conventional historical studies by including social class and gender. She advocated that other historians of women should reassess history through the perspective of women's experiences and voices.

In 1985, following Kelly's publication, Joan Wallach Scott presented an essay to the American Historical Association's conference where she argued that women and gender must become critical categories of historical analysis. ${ }^{6}$ In this work, Scott, defined gender as the "social organization of the sexes" (Scott 1986, p. 1054). With this definition in mind, she encouraged feminist historians to explore the complex meanings that were attributed to 'sexual difference' and how differences between the sexes were created by hierarchical social structures. She argued that a new history must emerge that does not include a separate history of women, but rather focuses on the complex nature of the relationship between the sexes. With this work, Scott challenged the conventional historian's claim that the male figure universally represented the historical subject. She argued that 'history' was an inherently masculinist discipline and she condemned the "gender-blindness" that was found in historical scholarship (Spongberg 2002, p. 10). By refusing to consider gender, male historians had created a "system of meaning" that excluded women, established women's subordination, and normalized their historical invisibility. She rejected traditional historical examples and undermined the male historian's "ability to claim neutral mastery or to present any particular story as if it were complete, universal and objectively determined" (Spongberg 2002, p. 10). Scott's essay showed that previous historical studies placed women, both as historical subjects and as historians, outside of history.

\subsection{Women and the Reformation}

There are two different approaches towards considering women in the scholarship on the Reformation and Martin Luther. Both approaches have been influenced by the emergence of

6 It was later published in 1986, see (Scott 1986), as well as (Lerner 1993). 
second-wave feminism and Women's History. The first approach focuses on the women and the Reformation movement. In the 1960s, Women's History contributed to an increase in scholarship in various fields that focused on including women's experiences of the past. Within this field, studies on this topic appeared relatively early in this wave of Women's History. For example, in 1971, Roland Bainton's work was one of the first studies to address women and the Reformation (Bainton 1971). With his work, he examined the contributions of sixteen women who played important roles in the Protestant and Catholic reform movements. ${ }^{7}$ He included biographical information on women of the sixteenth century from Germany and Italy. Along with these biographical sketches, Bainton also briefly evaluated the impact of the Reformation on women in society. For example, he argued that by moving away from celibacy, the Protestant Reformation provided women with a more respected role within the household. Although his work was mainly biographical, it included information on women who were not well known.

In 1972, other scholars, like Miriam Chrisman, Charmarie Jenkins-Blaisdell, and Nancy Roelker, contributed by publishing more analytical studies on women and the Reformation. In other words, these studies were not simply biographical sketches of women and they more critically analyzed the topic of women and the Reformation. For example, Chrisman explored women of the Reformation in Strasbourg by focusing on women's roles in the community and how they were affected by the Protestant Reformation (Chrisman 1972, p. 143). She argued that the Reformation did not contribute to any fundamental changes to women's position in society. Jenkins-Blaisdell examined how aristocratic women, like Renée de France, played important religious and political roles in the sixteenth century (Jenkins-Blaisdell 1972, p. 196). ${ }^{8}$ She primarily explored how Renée corresponded with reformist intellectuals, such John Calvin, and was an active supporter of the Protestant Reformation in France.

In the 1980s, scholars, like Joyce Irwin and Jane Dempsey Douglass, strongly emphasized the importance of examining women's experiences throughout the Reformation from their own personal perspectives including women's roles in society and explorations into how women influenced the Reformation movement. ${ }^{9}$

More recently in the 2000s, scholars, like Merry Wiesner-Hanks, take a similar approach as Irwin and Douglass. ${ }^{10}$ Recent studies tend to be biographies that focus on individual women, especially their impact and actions either in support or opposition of the Protestant or Catholic Reformations and their spiritual practices. ${ }^{11}$ For example, in 2009, Kirsi Stjerna published a work which built upon main arguments from Kelly and Irwin concerning the inclusion of women and gender-awareness within historical scholarship on the Reformation. She notes that historians have unfolded rich sources coming from women. Stjerna argues that these sources help Reformation scholars to create a more realistic and inclusive narrative of the Reformation, especially by "placing equal value on the roles and experiences of both sexes" (Stjerna 2009, p. 5). She argues that it can no longer be assumed that men were the active leaders within these movements and women were simply passive followers or that "women adopted the gendered world with its gender-biased options and parameters without scrutiny" (Stjerna 2009, p. 4). It can neither be assumed that the Reformation was equally experienced by men and women in the same manner. This is because history is much more complex. As with Kelly's insights about the Renaissance, Stjerna argues that by including women within historical evaluations, studies would be able to show a much more complete picture of history. It is for this reason that studies about women's experiences need to become more common in historical scholarship. Stjerna

7 The sixteenth women included: Katharina von Bora, Ursula of Münsterberg, Katherine Zell, Wibrandis Rosenblatt, Argula von Grumbach, Elisabeth of Brandenburg, Elisabeth of Braunschweig, Katherine Melanchthon and Anna Zwingli, Giulia Gonzaga, Caterina Cibo, Vittoria Colonna, Isabella Bresegna, Renée of Ferrara, and Olympia Morata.

8 Roelker's article is similar, in that, it examines the role that French noblewoman played in the French Reformation, see (Roelker 1972), pp. 168-196.See also (Davis 1975), pp. 65-96.

9 See (Irwin 1982), pp. 343-59, and (Douglass 1987), pp. 318-55.

10 See (Wiesner-Hanks 2000), and (Tucker 2017).

11 See (Wilson 2016), and (Wiesner-Hanks 1989). 
argues that these materials are still lacking and that "much more has been written about the wars, the Diets, and the reformers' assorted treatises than about how the Reformation was experienced [ ... ] by women" (Stjerna 2009, pp. 4-5). In attempting to address this problem, Stjerna produces biographical accounts to highlight women's leadership roles and contributions to the Reformation. She includes biographies on historical female figures such as Katharina von Bora, Queen Jeanne d'Albret, Ursula Jost, and Olimpia Morata, and many other women. Within her work, these women are introduced as history-makers and "as subjects of their own history," so that "there is hope for more inclusive history writing and theologizing" (Stjerna 2009, p. 6).

\subsection{Reformers' Attitudes towards Women}

The second approach to exploring women in relation to the Protestant Reformation addresses reformers' attitudes towards women by examining their theological or personal writings about women. This approach is not necessarily concerned with women's own personal experiences and perspectives, but rather more concerned with exploring reformers' attitudes towards women. Overall, scholarship has been slow to analyze Martin Luther's attitudes towards women. There are very few comprehensive studies have been published on the women in the lives and theologies of the reformers, especially works that evaluate their theology from gender perspectives (Stjerna 2009, p. 5).

This direction can be further broken down into two separate categories. First, there are scholars who try to explore Luther and the women in his life. This approach attempts to simply "add women and stir" to studies on Luther. This group tends to be composed of older works written from a confessional perspective. They frequently describe Luther in positive terms without providing much evidence to support their claims. As such, it is not the best approach to take towards examining Luther's perspectives. The second category explores Luther on women, and it will be the focus of this review.

\subsection{Scholarship on Luther and the Women in His Life}

Since the 1950s, biographies on Martin Luther, such as early works by Roland Bainton and Ewald Plass, have attempted, with limited success, to include depictions of Luther's "blissful" marriage. These depictions are typically used as short interludes between the crises of the early Reformation years and Luther's theological development. For this reason, Katharina von Bora, as Luther's wife, could hardly be excluded from the story. Even though scholars included Katharina in his life, she played a very minor role. Scholars, like Plass, were not interested in her as an individual. Instead, they were interested in using Katharina to reveal Luther's devotion to principle and his "great humanity." These claims were often unsubstantiated. For example, in 1950, Roland Bainton proclaimed that the "Luther who got married in order to testify to his faith actually founded a home and did more than any other person to determine the tone of German domestic relations for the next four centuries" (Bainton 1950, p. 223). In 1959, almost ten years later, Ewald Plass took a similar approach by stating: "Martin Luther's influence on marriage was profound and permanent" (Plass 1959, p. 884). However, these assertions have not been supported and they still remain to be proven.

In 1983, there was an increase in scholarship on Luther celebrating the five-hundredth anniversary of his birth. Although years later, published works, such as John Todd's study, presented Luther's marriage and personal life in much of the same way as earlier scholars (Todd 1982, pp. 260-67). While these studies presented Luther in a similar manner, other studies minimized the importance of his personal life. For example, Helmar Junghans published a two-volume set of essays which alleged to have included every important aspect of Luther's career; however, it did not give any attention to Katharina von Bora or any other women in his life (Junghans 1983). In 1990, Martin Brecht published a three-volume biography which dedicated a mere nine pages to the subject of Luther's marriage and life at home. At the end of the nine pages, Brecht states that "Luther was able to concentrate on his manifold tasks in such an atmosphere [his life at home] deserves our respect" (Brecht 1990, p. 204). In 1991, Gerhard Brendler took a similar approach to Luther's personal life as 
Brecht (Brendler 1991, pp. 302-10). Between the 1950s and 1990s, there were no major biographical studies that had sufficiently included women as subjects or evaluated Luther's attitudes towards women and whether he enforced his theological convictions about women and their "proper" roles.

\subsection{Luther on Women}

\subsubsection{Scholarship from the $1970 \mathrm{~s}$}

Scholars who were influenced by the new approaches in social history and the feminist movements from the 1960s recognized the value in considering the topic of Luther and women from a more critical perspective. In 1973, Martha Skeeters Behrens was one of the first scholars to argue that many aspects of Luther's life and thoughts have been examined; however, one area which has not been sufficiently explored is Luther's view women. Behrens argues that while there have been studies on Luther's ideas about the home, family, marriage, and sex, his ideas about women have received "only a sentence here and there" (Behrens 1973, pp. 1-2). She argues that is not because of a lack of existing material, but because of "a general neglect of the woman problem." This neglect has caused scholars to have an inadequate or incomplete understanding of Luther. Behrens and other scholars began to take a more inclusive look at Luther's writings concerning women in attempts to present a more nuanced picture. ${ }^{12}$ She argues that Luther's relationships with women take on more significance than simply revealing his humanity. Behrens' work argues that studies on Luther's view of women will at the very least broaden the context of Luther studies, and at most, signal "a new current in historical values" (Behrens 1973, p. 127).

Behrens' study explores Luther's theological view of natural woman and it discusses how his view contributed to the concept of female inferiority and evil, especially his comparison of women to Eve. This work is divided into three main parts. The first section explores Luther's theological views of the natural woman and the negative effects of these views on women. The second part of her work focuses on Luther's view of woman in society and she concludes that Luther's ideal of marriage defined his idea that woman belonged in the home. The third section explores Luther's view of woman and how it bears meaning on the Reformation itself.

It is important to note that Behrens highlights that Luther presents contradictory positions, especially regarding woman's natural inferiority versus punishment for original sin. ${ }^{13}$ Behrens' work appears early in scholarship and highlights the necessity to examine Luther and women, as well as his ambiguous approach. She notes that at certain points Luther presents a contradictory position which denies woman's natural inferiority and instead ascribed her restricted position in society to God's curse upon Eve. ${ }^{14}$ In other words, woman had her freedom taken away as part of a punishment for original sin. Behrens notes that it is unclear why Luther contradicted himself. In some instances, he argued that a woman's position in society was part of her punishment while in other cases, it was because of her natural inferiority. Behrens argues that it may be assumed that woman's role in original sin demonstrated her natural inferiority, even though this was contrary to Luther's statements that Adam and Eve were equal (Behrens 1973, p. 42). She continues with her exploration of the place of women in society and concludes that Luther's beliefs about woman's natural inferiority, along with his ideas about woman's punishment, meant that woman should not engage in matters pertaining to the church or state.

12 See (Wiesner-Hanks 1987), pp. 295-308, and (Karant-Nunn 1998), pp. 175-202.

13 Behrens provides excerpts from Luther's discussion on God's curse upon Eve from LW 1, 115; 202-3.

14 Behrens also points out that it is paradoxical that Luther seems to value woman's function in procreation but overlooks woman's role as a mother. She offers another paradoxical claim by highlighting that Luther's argument that motherhood was both a woman's reason for existing and also a punishment for sin; it was a sign of God's blessing and curse (for punishment, see LW 1, 200; for the function of a woman's body demonstrates God's blessing, see LW 1, 202); see also (Behrens 1973), pp. 61-62. 
However, Luther maintained some exceptions to his ideal of woman as passive. Behrens briefly highlights three women, namely Argula von Grumbach, Elisabeth of Brandenburg, and Katharina Zell. These women did not fit into Luther's "proper" roles for women. For example, she explains that Argula von Grumbach engaged in public protest when the faculty at the University of Ingolstadt forced a student to recant the teachings of Philipp Melanchthon. It was reported that Argula von Grumbach's punishment was the responsibility of her husband. Behrens notes that Luther's reaction to this situation is surprising when compared to his support to limit female activities. ${ }^{15}$ In a letter, Luther spoke of her as a "singular instrument" which Behrens argues may suggest that she was unique. However, he also calls her an "infirm vessel" which follows with most of his comments about women. As Behrens notes, Luther gave her actions "the authority of Christ" which made her an exception to his view that women should remain in the household and be subordinate to their husbands.

As for Katharina Zell, she was self-assured and strong, unlike Luther's ideal woman. Behrens notes that Luther was "faced with such notable exceptions to his description of woman" and that it is surprising that he "did not question his traditional view of her being and her place in the world" (Behrens 1973, p. 50). Rather, she argues that Luther continued to maintain traditional views as outlined in Genesis, Aristotle, and Paul.

One key contribution from this work is that Behrens explores Luther's theology and begins to compare his theological views to his personal relationships with women. Although this analysis is only discussed over a few pages, it nevertheless begins to analyze Luther's interactions with women. She notes that Luther would have had little contact with women when he was a monk, but that his later experiences brought him into closer contact with women. However, Behrens argues that, even after becoming a husband, Luther did not question his own theology. In other words, his view of woman remained the same throughout his life. Although Behrens presents Luther's theological views in a negative light, she nevertheless provides a detailed discussion of his theological attitudes towards women. ${ }^{16}$

\subsubsection{Scholarship from the $1980 \mathrm{~s}$}

In an article published in 1987, Merry Wiesner-Hanks challenges whether Luther held negative theological views on women by demonstrating the variation in assessments of his views through four contradictory statements. Two of these statements from Luther affirm a traditional or more negative approach while the other two show his compassion towards women (Wiesner-Hanks 1987, p. 295). This article contributes by highlighting the positive and negative positions held over the years in order to show that the range of opinions on Luther's ideas and their impact. ${ }^{17}$ Wiesner-Hanks engages with Martha Behrens' work in order to discuss how scholarship tends to emphasize Luther's negative views. The key finding from this article is that Wiesner-Hanks does not wish to add yet another interpretation to this debate since there is "ammunition enough in his writings to support any position" (Wiesner-Hanks 1987, p. 297). Instead, Wiesner-Hanks wishes "to retreat from that battlefield" and explore the language, images, and metaphors that Luther used when speaking about women.

By exploring how Luther defined the ideal woman, Wiesner-Hanks makes a distinction between what he considered the "female" and "feminine." She explains that the "female" refers to Luther's descriptions and discussions of actual women while the "feminine" is the use of imagery which stresses certain qualities like gentleness or submissiveness. According to Wiesner-Hanks, Luther's ideal woman was someone like Martha who remained within the home. His ideal woman was not

15 See WA BR 2, 509; WA BR 3, 706-9.

16 Behrens highlights Luther's negative views on women as exemplified with this quote: “Woman [ ... ] was limited to marriage and the realm of the household, forbidden that factor ultimately necessary to human dignity, choice. She served God by having children, served man by having sex, and served the spirituality of the whole world by staying home under the watchful eyes of her husband. This was Luther's woman in society," see (Behrens 1973), pp. 88-89.

17 For a negative approach, see (Behrens 1973), pp. 34, 95, for a neutral approach, see (Yost 1997), p. 164. 
Mary who tried to understand Christ's teachings better. She argues that women who appear in his writings are sometimes depicted in positive ways. However, throughout Luther's writings, even the words used to describe the ideal woman were "hardly complimentary ones-a weak vessel, a nail, a tortoise - and those used to describe women who do not follow the ideal even harsher-burning with lust, stinking, tools of the Devil and so on" (Wiesner-Hanks 1987, p. 302). Therefore, this article argues that the "female" image from Luther's works is an ambiguous one. This finding is perhaps the key contribution from this article because it argues that scholars should take a step back from the debate about Luther's impact on women in order to reconsider his statements about women, especially in light of such existing ambiguities. This article initiates a new dialogue that seeks to discuss his ambiguous approach to women rather than offering yet another interpretation to support whether Luther's views had a positive or negative impact for women.

\subsubsection{Scholarship from the $1990 \mathrm{~s}$}

In 1991, Albrecht Classen and Tanya Settle published an article attempting to explain why Luther's ambiguities exist. They examine how Luther's interactions with women may have influenced his theology and illuminate the function that Luther ascribed to women (Classen and Settle 1991, p. 231). Specifically, these authors explore Luther's views on marriage and women. They examine his sermons on marriage and include a discussion of his relationships with various women including his mother, wife, and other Reformation women activists like Katharina Zell and Argula von Grumbach. This article outlines Luther's theological views and examines his relationship with actual women because "his sermons do not tell the whole story" (Classen and Settle 1991, p. 238).

Classen and Settle argue that Luther, as a monk, would not have been concerned with women, but this changed when he married Katharina von Bora. These two authors argue that Luther "soon seems to have deviated from his previous rigid opinions about women and marriage as such, once he came into closer contact with them" (Classen and Settle 1991, p. 232). Classen and Settle note that Luther did not extensively discuss his attitude toward his mother, but his relationship with his wife "left definite historical traces." Classen and Settle argue that these traces "need to be closely examined and discussed in light of modern feminist notions of the history of women in the Middle Ages and the early modern period" (Classen and Settle 1991, p. 233). His relationships with women deserve more scholarly attention since there is a lack of scholarship on how Luther interacted with women, how he treated them, and finally the extent to which he was open to accept their influences.

Classen and Settle conclude that Luther's theology about marriage, at least his early theology, had a negative impact for women. It did not provide women with a new social or theological position in life since he reaffirms man's patriarchal role. In this way, woman is submissive to her husband and should accept her role or fate as God-given. It seems that this article is presenting Luther's more negative perspectives; however, it is important to note that the authors make it explicit that their analysis of Luther's views would change if they examined his more mature theology. They note that they only examined Luther's theology from an earlier time in his career before he came into closer contact with women.

As with any work, there are limitations to this study. For example, there is not enough engagement between Luther's theological perspectives and personal correspondence with women. Second, this article focuses solely on his theology on marriage and does not consider other theological works, such as his commentaries on Genesis, that address women. Third, although it does acknowledge that Luther's theology likely developed over his life, it does not provide enough evidence to support this claim. For instance, the authors only consider Luther's earlier theology and they do not examine his more mature theology in their article. It would be impossible to say whether Luther's theology changed over time unless both his earlier and later theology are examined. The authors would need to include a discussion of Luther's more mature theology to support their claim. In this way, the article also does not provide an analysis that offers a clear distinction between Luther's earlier theology and his later theology. 
Nevertheless, this article highlights the necessity to test Luther's theology in the context of his personal relationships with actual women. It claims that the later Luther deviated from his theological attitudes towards women, especially from his early period. Finally, it argues that if scholars were to examine Luther's theology alone, it would seem as though Luther tried very hard to keep women within the household. Yet, when his personal relationships with women are considered, it shows the considerable respect Luther held for women. This article argues that ambiguities exist and that scholars need to further explore Luther's personal correspondence with women, as well as theological attitudes, in order to explain these complexities and apparent contradictions.

In attempts to further explore Luther's attitudes towards women, scholars began to focus on his theological perspectives, especially in the 1990s. For example, in 1992, Kristen Kvam explores features of Luther's theological understanding of women by examining his response to the "Woman Question" or "Frauenfrage" as outlined in his lectures on Genesis. ${ }^{18}$ Specifically, she focuses on Luther's interpretation of Eve in order to investigate his understandings how women relate to men and their nature, especially by focusing on his exegetical discussions. Kvam observes that scholars "have not totally neglected Luther's response to the Woman Question" (Kvam 1992, p. 14). For example, there are several anthologies that have referenced Luther's statements about womanhood. ${ }^{19}$ However, although some secondary sources have referenced Luther's views on womanhood, a more substantial investigation is needed. Kvam notes that an exhaustive study of his attitudes towards women is merited, but is beyond the scope of her study.

Nevertheless, Kvam's work contributes by researching and assessing Luther's theological understandings of Eve's character and activity. Kvam argues that "embedded on the edges of many of Luther's theological considerations are his understandings of the significance of gender and gender relations for Christian anthropology as well as his views upon the particular identity of women" (Kvam 1992, p. 4). The purpose of her work is to argue that his theological writings contain important resources for creating a Christian anthropology that "presents equality and mutuality rather than hierarchy and opposition as paradigmatic for what it means to be male and female." This work suggests ways in which Luther's understandings of womanhood provide a catalyst for reforming Christian anthropologies that support the gender hierarchy of men over women as being part of God's design. This study demonstrates how Luther's ideas about Eve are complex and that she holds a fundamental position for Christian understandings of the female: "The impact of the character of Eve arises out of her particular place in the Christian story. Eve is not simply one biblical woman among others; in the biblical story she is the first woman" (Kvam 1992, pp. 21-22). Luther frequently wrote about Eve because she was not only viewed as the first woman, but also as a representative of womanhood more generally.

In 1997, Adam Hill wrote a thesis which examines Luther's theological approach to women, specifically focusing on his biblical commentaries (Hill 1997). He argues that although Luther's theology appears to be liberating to women, it was used to further oppress them. His work focuses on the two vocations available for women; marriage and monastic life. Hill focuses on Luther's religious legitimation of marriage and the celibate life. He argues that Luther's theology was not concerned with the religious status and women's function, but had other concerns. For Hill, this was his principle theological concern with the place of faith and works in Christian theology as seen with his doctrine of justification by faith alone. Hill argues that Luther's theology concerning the direct responsibility of individuals before God could have provided women with more freedom, but it did not. Hill uses Teresa of Avila as an illustration of this idea since her arguments to justify monasticism do not contradict

18 The "Woman Question" refers to a number of issues that are brought together by inquiries into the meaning of womanhood: "While the 'Woman Question' may be pursued from a variety of angles, the overarching concern revolves around perceiving female human persons as a distinct collective and inquiring into the character and activity that the members of this group share." See, (Kvam 1992), pp. 3-4, and (Kelly 1982).

19 See (Clark and Richardson 1977), pp. 131-48, and (O'Faolain and Martines 1973), pp. $195-98$. 
Luther's theological claims about abolishing monastic life for women. Rather, Hill argues that Luther's "own tendency to overreact to that which superficially appeared to stand against him," resulted in his poor theological reasoning (Hill 1997, p. 69). Hill focuses on Luther's sermons and treatises in order to analyze his comments about Mary to show that Luther struggled with issues of sexual intercourse, marriage, and the celibate lifestyle.

Adam Hill acknowledges that Luther's attitudes toward women were ambiguous at best. Hill points out that these ambiguities do exist, especially in Luther's position on sexual intercourse within marriage: "Luther's self-contradictions on this matter portray a man who was struggling with this issue himself. His statements, when taken together, present a rather ambiguous position" (Hill 1997, pp. 46-47). However, Hill does not retreat from offering his own opinion on Luther's negative impact on women despite acknowledging that these ambiguities do exist. It is also interesting to note that Hill does not incorporate this issue into his broader discussion on Luther's theology, especially pertaining to women. He mentions that Luther held a rather ambiguous position, but only discusses this problem in passing with approximately a page worth of information. Previous scholarship emphasizes that Luther's ambiguous theological statements about women deserve much more attention. Therefore, it is surprising that Hill did not include this in his examination since it provides much more context to Luther's position on women, especially in relation to his commentaries on Genesis. Unlike Wiesner-Hanks' previous study, Hill's work does not contribute to exposing Luther's ambiguous perspectives because it primarily focuses on how Luther's theology could have liberated women, but instead further oppressed them.

\subsubsection{Scholarship from the 2000s}

In 2003, Susan Karant-Nunn and Merry Wiesner-Hanks acknowledged that there had not been adequate growth in the field with regards to Luther's views on women. Due to this, they published a sourcebook which translated and edited Luther's writings about and to women. These two editors argue that they have both explored different aspects of women's lives during the Reformation period and that they expected that these studies would have been connected by other scholars' analyses of Luther's ideas about women. ${ }^{20}$ However, they argue that this has not happened to the extent that it should. They note that there is still no book-length study on Luther's ideas about women in any language. This prompted them to assemble and translate his works. By collecting and translating in English several of Luther's writings and statements about women, the authors are optimistic that this will help begin to fill this void in scholarship on Luther and women (Karant-Nunn and Wiesner-Hanks 2003 , p. 2). The editors wanted to make Luther's writings available to an audience that may not be fluent in New High German or Latin. They also note that they included their source citations to make it easier for specialized scholars to find the passages in their original languages. Therefore, this work benefits audiences who are not trained academics, as well as Luther scholars who can now easily find relevant sources. The authors hope that by providing translations and citations that it will "open the floor of wider discussion of the significance" of women in the sixteenth century (Karant-Nunn and Wiesner-Hanks 2003, p. 2).

They include primary source material from sermons, letters, lectures, and material from the Table Talks, and shorter excerpts from larger works. The editors chose, mainly for clarity, to present the sources by theme and not chronologically. Each chapter has a short introduction which summarizes Luther's views on the theme and provides additional context by comparing them to the views of other reformers like John Calvin.

One limitation of this work, which is acknowledged by the editors, is that they are both trained as historians and not as theologians, so they make very few theological comments. They state that they "had long hoped someone else would write [this book] for them" because they are not specialists in

20 See (Karant-Nunn 2012), and (Wiesner-Hanks 2000). 
Luther's ideas (Karant-Nunn and Wiesner-Hanks 2003, p. 2). Due to this, the reader is forced to look elsewhere for a study that engages with relevant theological concepts. For example, the doctrine of vocation, priesthood of all believers, and the theology of the cross, could all help to enrich scholars' understanding of Luther's theological attitudes towards women. It is also interesting to note that the editors advise their readers that Luther's theological ideas changed over the twenty-five years (1521-1546) and that he did not hold consistent views, but they do not provide specific examples of these apparent inconsistencies. For example, they state "because he said so much, however, his ideas about sexuality, like his ideas about women, often appear contradictory" (Karant-Nunn and Wiesner-Hanks 2003, p. 139). The editors do not explain further whether they meant that the statements merely appear contradictory or are in fact contradictory claims themselves.

This work contributes by assembling relevant primary source materials on Luther and women in one sourcebook. In addition, the editors translated several works not previously available in English. Therefore, this work acknowledges the necessity to make sources more easily accessible for non-academics and Luther specialists. They hope that this will help to inspire future conversations because there has yet to be a comprehensive study that examines both Luther's theology and personal encounters with women.

In 2003, Mickey Mattox's work helps to fill this void. Mattox's work focuses specifically on Luther's exegesis and attempts to better characterize how he treated the women of Genesis by examining his exegetical work and comparing it to other Christian exegetes (Mattox 2003, pp. 3-4). Mattox argues that Luther's interpretation of these women remains within the frame of traditional exegesis which was common among his predecessors and contemporaries. In other words, his interpretation was "traditional," but not necessarily "conventional." Mattox hopes to contribute to a better understanding of Luther as part of the Christian exegetical tradition, but also illuminate what Lyndal Roper terms the "theology of gender" (Roper 2001, pp. 108-9). Mattox argues that biblical exegesis has had a significant role in "imagining and legitimating the social construction" of early modern society. He argues that the "examination of Luther's interpretation of the women of Genesis will show how Luther and other exegetes envisioned human society in a fallen world, and how they dealt with moral and theological questions related to the actions of women in the problematic situations common to the story of Genesis" (Mattox 2003, p. 3). By choosing women of Genesis to discuss, he is able to address important questions related to the role of women in society, especially within the context of the sixteenth century. However, Mattox is more concerned with the ways in which Luther was able to combine traditional exegetical approaches to these biblical women with his own insights. Although this work focuses on his comments on women, it is significant to point out that Mattox's work is primarily a study of Luther and his exegetical method.

Mattox divides his discussion of Luther's theological views into two categories. First, he presents a discussion of a young Luther's exegesis of Genesis 1-3 which is found in his Declamationes in Genesis (1523-1524). ${ }^{21}$ Following this, Mattox analyzes Luther's more mature and different interpretation of Eve from his Lectures on Genesis (1535-1545) both in the context of Philip Melanchthon's exegesis and other reformed commentators. These first two chapters examine his changing opinion of Eve. It portrays the differences between the young and elder Luther in this analysis of Eve. Mattox argues that Luther's paradoxical claims about Eve in his Lectures are "not ultimately contradictory but present a generally coherent view of Eve and her position" (Mattox 2003, p. iv). Rather than contradictory, Mattox argues that Luther's mature concept of Eve should be considered as a development of his exegesis. Mattox's third chapter places the later Luther's interpretation of Eve in the context of his contemporaries, especially Philip Melanchthon and Ulrich Zwingli. By reading Luther and his contemporaries so widely, Mattox not only draws conclusions about the mature Luther's interpretation of Eve, but also about Luther's overall place in the exegetical tradition. Chapters four and five analyze Luther's

21 Published in 1527. 
interpretation of six different biblical women in Genesis. Mattox also provides background for Luther's exegesis by discussing the exegesis of Origen, Ambrose, and John Chrysostom in order to further illuminate Luther's place in the history of exegesis. This is an important aspect of this work because it examines Luther's interpretations of six biblical women and compares them to patristic, medieval, and reformed commentators. This provides a discussion on Luther's general understanding of women stemming from his interpretations of biblical women. However, a more nuanced understanding of Luther's attitudes towards women requires the additional perspectives. Luther's views on women, and perhaps even the extent of his inconsistencies, become more evident when one explores beyond his biblical commentaries.

Seven years later, in 2010, the lament for more comprehensive studies on Luther and women continued to be heard by scholars such as Else Marie Wiberg Pedersen. Pedersen's work acknowledges Wiesner-Hanks' and Karant-Nunn's sourcebook by stating that it was the first time that English translations of Luther's writings about women were made available (Pedersen 2010). Pedersen notes that this sourcebook demonstrates that Luther held a complex view of women and his writings appear binary in nature on the genre and audience. For example, Pedersen notes that within Luther's commentaries on Genesis 1-3, a traditional exegesis is present. However, she also highlights that within these very same texts, Luther employs positive formulations regarding the relation between male and female theologically. This article attempts to explore these apparent ambiguities in Luther's approaches to women by discussing his theology, specifically focusing on his commentaries on Mary and the Magnificat. This article argues that throughout his theology, we get a picture of an individual who is conflicted between his more modern ideas about women and the traditional views of his time: "He is a man caught between bad anthropology and good theology" (Pedersen 2010, p. 193). This article acknowledges that it is unable to discuss all aspects, but attempts to provide a balanced presentation of his attitude towards women. This article argues that scholars should sufficiently analyze Luther's texts more comprehensively including hermeneutically, rhetorically, and intertextually.

However, Pedersen also argues that we should "ignore Luther" whenever he draws on his "bad anthropology," especially when he discussed the ministry of the word (Pedersen 2010, p. 195). She argues that Luther's "good theology" can be seen with Luther's Mariology, where Pedersen argues that the Holy Spirit does not exempt women from being fully rooted in the gospel. According to Pedersen, Luther's "good theology" is challenged by his "bad anthropology." For this reason, Lutherans should "call him back" to his "good theology" and only develop Lutheran theology from his "good theology." However, ignoring Luther's possible flaws, ambiguities, or inconsistencies does not completely acknowledge his complexities and does not help to explain why ambiguities between his "bad anthropology and good theology" exist in the first place.

Despite this, Pedersen's work explicitly notes the importance of contextualization which is significant. She notes three important aspects. First, Pedersen argues that when Luther addressed women as a subject, it is difficult to determine which statements are rhetorical or symbolic versus what are ontological statements. Second, she argues that scholars should acknowledge that some of Luther's statements are ambiguous or even self-contradictory, and that it is important that readers are aware of these possibilities. Finally, some of Luther's statements about women and their nature come from his Table Talks. Scholars should take care when assessing these statements since they are often second-hand accounts: "They are neither from Luther's own pen nor do they incorporate the conversation or discussion into which these formulations allegedly fell" (Pedersen 2010, p. 193). Pedersen points out that Luther's disciples may have taken him more seriously than he took himself, especially when many comments "may have poured out humorously while Katharina's famously good beer was pouring in" (Pedersen 2010, p. 193). Pedersen argues that these statements sharply contrast with his own life among women. For this reason, she argues that the relationship between Luther's theology and personal interactions with women should be examined by future scholarship. 


\subsubsection{Scholarship from the Past Two Years}

In June 2017, Kirsi Stjerna published a short article which addresses the topic of Luther and gender. In this article, she argues that "the topic of sex, gender, and women has not attracted rigorous study from 'serious' Luther scholars of the past" (Stjerna 2017b, p. 162). Even as recently as 2017, Stjerna argues that this methodology and "interest" gap is still "palpable," especially when examining previous studies on Luther. She notes that this gap is not only obvious, but it is "anything but helpful" (Stjerna 2017b, p. 163). Stjerna argues that the topic of Luther and women has been either overlooked or unsatisfactorily expanded in previous Luther scholarship. Her article argues that this gap is odd because when scholars look at his commentaries on Genesis, we can see that he paid considerable attention to women and gender in his theological works. However, the theological study of Luther has often ignored questions regarding women and gender. Since there has been a lack of studies, an important aspect of the "essential" Luther has remained in the dark. The main purpose of Stjerna's article is to argue that gender questions and approaches are not marginal, but rather central to the study of Martin Luther.

With this article, Stjerna discusses the inclusive translating of Luther's works. She argues that modern editions of Luther's works have creatively addressed the "unnecessarily male-oriented language favored by earlier generations." 22 She argues that previous editions of Luther's Works reflect the common use in English of referring to human beings with the male-pronoun. Stjerna argues that by "looking at the original wording, and attending to Luther's theological intent, however, it is clear that such translation choices are not only problematic and unnecessary in our time, but also do not yield the most faithful translation of Luther's theology" (Stjerna 2017b, p. 163).

With the rest of her article, she provides her observations from reading Luther's Lectures on Genesis and his interpretation of Eve. She argues that based on the space and careful detail "with which the deliberations on all matters regarding Eve, and the tenderness with which he treats the matriarchs in the Genesis narrative" show that this topic was not a marginal interest for Luther (Stjerna 2017b, p. 164). However, Stjerna is limited by the confined space of a short article to sufficiently tackle such a complex issue. Nevertheless, her work has many strengths. It highlights the continued necessity to examine the topic of Luther and women. At the very end of her article, she provides an important insight. Stjerna notes that Luther's statement that men and women "only" differ in sex points to something more significant:

"There remains a certain dissonance between Luther's perception of the biblical women and of the women of his time. The women in his day did not receive from Luther a welcome to the pulpit or equality in the affairs of the church and society - at least not generally speaking, with only a few exceptions (as with Argula von Grumbach). Luther's theology, though based on a vision of equality in creation, is faulty in its application in real life, where influences other than the Bible shaped Luther's logic" (Stjerna 2017b, p. 167)

This comment is valuable because Luther's theology becomes problematic or faulty when we look at his personal life with women. There are other influences in Luther's personal life that shaped his thinking. These are two comments that help to highlight the importance of studying not only Luther's theology, but also his personal life and interactions, especially with women. Stjerna does not offer any further comments on this approach, but it is important that previous scholarship has acknowledged the significance of Luther's own life. However, previous scholarship has not adequately examined Luther's theological works and its application in real life. Stjerna argues that previous studies have typically approached Luther without considering his interactions which has made him "seem alien to the very women with whom Luther, actually, could be quite a conversation partner" (Stjerna 2017b, p. 163).

22 For example, The Annotated Luther fills many gaps, see (Luther et al. 2017). 
On 4 December 2017, Kirsi Stjerna published a chapter in an extensive book, edited by Alberto Melloni, which deals with seemingly every aspect of Martin Luther (Stjerna 2017a, pp. 597-615). At the beginning of this chapter, Stjerna notes that the words "Luther and women" bring up several possible avenues for further exploration. For example, how Luther's writings impacted women, how women supported or challenged his theology, how he interacted with women, how he wrote about women, and how women studies and Luther scholarship intersects. She states that the answers to these possible avenues or questions are "incomplete" and that even more "uncharted research areas [concerning Luther and women] can be named, pointing to different sources, questions, and methods." One important area that Stjerna mentions for future research is the "personal." She poses the question: "What do we know of Luther's relationship with women of his time - his family, friends, and associate?" (Stjerna 2017a, p. 597). She argues that Luther's personal interactions offer scholars helpful insights into this question, but that it is an "underexplored window."

This chapter begins with a brief comment on Luther's influence on women then shifts to emphasize his ideas of women while considering his personal relationships and correspondence. She argues that it "seems that in the case of Luther, theory and actual reality do not always neatly correlate" (Stjerna 2017a, p. 614). The chapter concludes by presenting Stjerna's brief observations on his exegetical work with women of the Bible. Throughout her chapter, Stjerna brings together the relevant scholarship on Luther and women to show that there is still much work that needs to be done. Once again, Stjerna's work is emphasizing the necessity for future scholars to thoroughly examine Luther's theology while also considering his personal relationships with women. With this chapter, Stjerna is highlighting the necessity for future scholars to examine the topic of Luther and women, especially considering his theology and personal correspondence. She states that "Luther can hardly be understood without 'his' women, just as women today can except to be pleasantly surprised by their critical and compassionate conversations with Martin Luther" (Stjerna 2017a, p. 615). She concludes her chapter by arguing that "a deeper and broader analysis is still needed when it comes to Luther's treatment of the topic of women - in his various texts and in the light of his context - in order to unveil his truest instincts and intentions" (Stjerna 2017a, p. 615).

In December 2017, Sini Mikkola produced an outstanding doctoral dissertation which examines Luther's theology of the body, specifically his view of gender and bodiliness (Mikkola 2017). It is important to note that she provides a novel contribution because she focuses heavily on Luther's views of the male body and masculinity which are topics that have received little interest from scholars in the past. I anticipate that her work will greatly contribute to the field when it is published. From her doctoral research, she notes that "it is not the difference between theory and practice per se that is pervasive in Luther's texts but rather a continuity, or discontinuity, between theory and practice, which is dictated by the context and the overall situation" (Mikkola 2017, p. 240). ${ }^{23}$ With her study, she examines Luther's composition of the human being, body and flesh, bodily needs, sexuality, construction of the female and male body, and bodiliness in Luther's marriage. Mikkola argues that Luther's attitudes towards gender are fundamental in his theological writings of the human being, sexuality, and the body. She notes that even though his discussion did not always include "bodiliness," it is possible to obtain his perspective on gendered bodiliness by reading between the lines.

Mikkola's dissertation first examines how Luther treated gendered bodiliness in his theological works, especially in his discussions of femininity and masculinity. Her work notes that the body played a significant role in Luther's writings. She focuses on a variety of Luther's texts from the perspective of themes of bodiliness and gender. Mikkola argue that his works show the ways in which he constructed proper feminine and masculine norms, roles, and characteristics.

23 In an article from 2015, Sini Mikkola explores how Luther constructed female otherness. She states in her own work that the contents of this article are part of her (then) uncompleted doctoral thesis. Therefore, I did not include a separate section on this article in my review because the very same information is included in her dissertation, see (Mikkola 2015), pp. 175-85. 
Sini Mikkola's work explores whether Luther's perspectives varied according to historical and textual contexts. Her study focuses especially on whether there are differences between his attitudes towards female and male ways of being that are outlined in theory and his practical situations. Mikkola argues that it is important to analyze Luther's "real-life situations." She states that these situations reveal that Luther "could in practice be flexible in his viewpoints concerning the limits that one's gender constituted - he allowed different rules for himself, for instance" (Mikkola 2017, p. 253). She argues that whether Luther applied his theology of the body in practice depended on the situation. However, she argues that "in many cases regarding his fellow men and women he applied his theoretical views in practice in a very strict sense" (Mikkola 2017, p. 253). For example, she points to how Luther applied his thinking of masculinity to men in real-life. She focuses on male figures, such as Philipp Melanchthon, who seemed to be a special case for Luther: "Melanchthon's fragility - even pitifulness, as Luther called it - became an ideal masculinity that he opposed against the masculinity of the early church theologians" (Mikkola 2017, p. 235). In this way, Melanchthon's gendered way of being was not used as an ideal representation, but rather "used and turned around" by Luther.

Mikkola argues that there are two core ideas that underline Luther's relationships with men and women. First, the closer the individuals were to Luther, such as Katharina von Bora or Philipp Melanchthon, the more special the case. Second, whether the situation was strategically important for Luther and his Reformation message, such as Katharina Zell and Frederick the Wise, the more special the case. Mikkola concludes her study by stating that in other cases Luther "did not tolerate - or he tolerated far less - transgressions of his norms concerning the gender system" (Mikkola 2017, p. 240).

Mikkola's work is an excellent study that provides a thorough examination of Luther's views of gendered bodiliness and gendered systems, especially including a feminist perspective. Mikkola makes an important remark by stating that "Luther's general evaluation of women can be seen in his writing to women" (Mikkola 2017, p. 237). With this comment, she emphasizes the importance of moving beyond Luther's theology and examining his personal correspondence with women. Her study proves that scholars can discover Luther's perspectives on a variety of topics, including gendered bodiliness, by reading between the lines and considering his personal situation. By applying this method, Mikkola's study provides scholars with new insights on Luther, especially with regards to his views of masculinity and femininity. Her work shows that this unique perspective could not have been obtained by solely examining Luther's theological writings. Therefore, Mikkola's work confirms the value of considering the practical, as well as the theoretical. Her study proves that this method is the most promising approach for future scholarship, especially for works on Luther's theology and feminism. These previous studies have highlighted the necessity for future scholars to continue to explore Martin Luther's attitudes towards women and have argued that the most fruitful approach to revealing new perspectives is to include an analysis of both his theology and personal life. ${ }^{24}$

\section{Conclusions}

It is clear from this review that previous scholarship has acknowledged the necessity to examine Martin Luther and women. It is important that we do not forget that Luther was an emotional person living a vigorous life. In other words, Luther was a complex individual who not only wrote about women, but also interacted with women in his public and private life. Scholars have also highlighted the necessity to measure the extent to which Luther was committed to enforcing his theological principles in his own life. As Luther's views, both directly and indirectly, came to have authority in the Reformed Church and in society more broadly, it is important that scholars continue to investigate any apparent contradictions, ambiguities, and complexities, especially in light of Luther's personal

24 In my doctoral dissertation, completed in 2019, I argue that Martin Luther's attitudes towards women are not only discovered by exploring his theological works, but also by examining his personal experiences and correspondence. I am also currently preparing a manuscript for publication based on my dissertation research. 
encounters with women. Although progress has been made with research on Luther and women, scholars need to continue to pursue a critical investigation of Luther's perspectives, especially from a feminist perspective. My hope is that this review not only provides a framework for reading the scholarly contributions in this Special Issue of Religions, but that it also highlights the importance of exploring Martin Luther's theological attitudes towards women and his interactions with women from the dual perspective of theory and practice.

Funding: This research received no external funding.

Conflicts of Interest: The author declares no conflict of interest.

\section{Abbreviations}

LW Martin Luther. Luther's Works. Translated by Jaroslav Pelikan. St. Louis: Concordia, 1955-1986.

WA Martin Luther, D. Martin Luthers Werke: Kritische Gesamtausgabe, Briefwechsel. 18 vols. Weimar:

BR Hermann Böhlaus Nachfolger, 1930-1985.

\section{References}

\section{Primary Sources}

Karant-Nunn, Susan, and Merry Wiesner-Hanks. 2003. Luther on Women: A Sourcebook. Cambridge and New York: Cambridge University Press.

Luther, Martin, Hans Hillerbrand, Euan Cameron, Kirsi Stjerna, and Timothy Wengert. 2017. The Annotated Luther. Minneapolis: Fortress Press.

\section{Secondary Sources}

Bainton, Roland. 1950. Here I Stand: A Life of Martin Luther. New York: New American Library.

Bainton, Roland. 1971. Women of the Reformation in Germany and Italy. Minneapolis: Augsburg Publishing House. Behrens, Martha. 1973. Martin Luther's View of Woman. Master's Thesis, North Texas State University.

Brecht, Martin. 1990. Martin Luther: Shaping and Defining the Reformation, 1521-1532. Translated by James Schaaf. Minneapolis: Fortress Press.

Brendler, Gerhard. 1991. Martin Luther: Theology and Revolution. Translated by Claude Foster Jr.. New York and Oxford: Oxford University Press.

Burke, Peter. 1992. History and Social Theory. Ithaca: Cornell University Press.

Chadwick, Owen. 1972. The Reformation. Harmondsworth: Penguin.

Chrisman, Miriam. 1972. Women of the Reformation in Strasbourg 1490-1530. Archive for Reformation History 63: 141-68. [CrossRef]

Clark, Elizabeth, and Herbert Richardson. 1977. Women and Religion: A Feminist Sourcebook of Christian Thought. New York: Harper and Row.

Classen, Albrecht, and Tanya Amber Settle. 1991. Women in Martin Luther's Life and Theology. German Studies Review 14: 231-60. [CrossRef]

Davis, Natalie Zemon. 1975. City Women and Religious Change. In Society and Culture in Early Modern France. Standford: Standford University Press, pp. 65-95.

Douglass, Jane. 1987. Women and the Reformation. In The Many Sides of History: Readings in the Western Heritage. Vol. 1: The Ancient World to Early Modern Europe. Edited by Steve Ozment and Frank M. Turner. New York: Macmillan, pp. 318-35.

Hendrix, Scott. 2017. Martin Luther: Visionary Reformer. New Haven: Yale University Press.

Hill, Adam. 1997. Martin Luther, Marriage, and Women: An Analysis of Luther's Religious Legitimation of Marriage and the Celibate Life for Women in His Sermons and Treatise. Master's Thesis, University of Calgary, Calgary, AB, Canada.

Howell, Martha, and Walter Prevenier. 2001. From Reliable Sources: An Introduction to Historical Methods. Ithaca: Cornell University Press. 
Irwin, Joyce. 1982. Society and the Sexes. In Reformation Europe: A Guide to Research. Edited by Steven Ozment. St. Louis: Center for Reformation Research, pp. 343-59.

Jenkins-Blaisdell, Charmarie. 1972. Renée de France Between Reform and Counter-Reform. Archive for Reformation History 63: 196-226.

Junghans, Helmar. 1983. Leben und Werk Martin Luthers von 1526 bis 1546. Göttingen: Vandenhoeck \& Ruprecht. Karant-Nunn, Susan. 1998. The Reformation of Women. In Becoming Visible: Women in European History. Edited by Renate Bridenthal, Susan Mosher Stuard and Merry Wiesner-Hanks. Boston: Houghton-Mifflin, pp. 174-201.

Karant-Nunn, Susan. 2012. The Reformation of Feeling: Shaping the Religious Emotions in Early Modern Germany. London: Oxford University Press.

Kelly, Joan. 1977. Did Women Have a Renaissance? Boston: Houghton Mifflin.

Kelly, Joan. 1982. Early Feminist Theory and the 'Querelle des Femmes. ' Signs: Journal of Women in Culture and Society 8: 4-28. [CrossRef]

Kvam, Kristen. 1992. Luther, Eve, and Theological Anthropology: Reassessing the Reformer's Response to the 'Frauenfrage.'. Ph.D. dissertation, Emory University, Atlanta, GA, Canada.

Lerner, Gerda. 1979. The Majority Finds Its Past: Placing Women in History. New York: Oxford University Press.

Lerner, Gerda. 1993. Scholarship in Women's History: Rediscovered and New. New York: Carlson Publishing.

Mattox, Mickey. 2003. Defender of the Most Holy Matriarchs: Martin Luther's Interpretation of the Women of Genesis in the Narrations of Genesis, 1523-45. Leiden: Brill.

Mikkola, Sini. 2015. Female as the Other in Martin Luther's Anthropology in the Early 1520s. Anthropological Reformations: Anthropology in the Era of the Reformation 28: 175-85.

Mikkola, Sini. 2017. 'In Our Bodies the Scripture Becomes Fulfilled': Gendered Bodiliness and the Making of the Gender System in Mature Luther's Anthropology (1520-1530). Ph.D. thesis, University of Helsinki, Helsinki, Finland.

Mitchell, Juliet. 1966. Women: The Longest Revolution: Essays on Feminism, Literature and Psychoanalysis. London: Virago Publishing.

O'Faolain, Julia, and Lauro Martines. 1973. Not in God's Image: Women in History from the Greeks to the Victorians. New York: Harper and Row.

Pedersen, Else Marie Wiberg. 2010. A Man Caught Between Bad Anthropology and Good Theology? Martin Luther's View of Women Generally and of Mary Specifically. Dialog: A Journal of Theology 49: 190-201. [CrossRef]

Plass, Edwald. 1959. What Luther Says: An Anthology. St. Louis: Concordia Publishing Company.

Power, Eileen. 1975. 1975. Medieval Women. Cambridge: Cambridge University Press.

Rahikainen, Marjatta, and Susanna Fellman. 2012. On Historical Writing and Evidence. In Historical Knowledge: In Quest of Theory, Method and Evidence. Edited by Susanna Fellman. Newcastle: Cambridge Scholars Publishing, pp. 5-45.

Roberts, John. 1976. History of the World. New York: Knopf.

Roelker, Nancy. 1972. The Role of Noblewomen in the French Reformation. Archive for Reformation History 63: 168-96. [CrossRef]

Roper, Lyndal. 2001. The Holy Household: Women and Morals, in Reformation Augsburg. Oxford: Clarendon Press.

Scott, Joan Wallach. 1986. Gender: A Useful Category of Historical Analysis. The American Historical Review 91: 1053-75. [CrossRef]

Spongberg, Mary. 2002. 'Hardly any Women At All'? Women Writers and the Gender of History. In Writing Women's History Since the Renaissance. Hampshire: Palgrave Macmillan, pp. 1-8.

Stjerna, Kirsi. 2009. Women and the Reformation. Oxford: Blackwell Publishing.

Stjerna, Kirsi. 2017a. Luther and Women. In Martin Luther: A Christian between Reforms and Modernity (1517-2017). Edited by Alberto Melloni. Berlin: De Gruyter, pp. 597-615.

Stjerna, Kirsi. 2017b. Luther and Gender: Shifts in Paradigms and Orientations. Dialog: A Journal of Theology 56: 162-68. [CrossRef]

Todd, John. 1982. Luther: A Life. New York: Crossroad.

Tucker, Ruth. 2017. Katie Luther, First Lady of the Reformation: The Unconventional Life of Katharina von Bora. New York: Harper Collins Publishing.

Umansky, Lauri. 2000. Making Sense of Women's Lives. Lanham: Rowman \& Littlefield Publishers. 
Wiesner-Hanks, Merry. 1987. Luther and Women: The Death of Two Marys. In Disciplines of Faith: Studies in Religion, Politics, and Patriarchy. Edited by Jim Obelkevich, Lyndal Roper and Raphael Samuel. Long and New York: Routledge and Kegan Paul, pp. 295-310.

Wiesner-Hanks, Merry. 1989. Nuns, Wives, and Mothers: Women and the Reformation in Germany. In Women in Reformation and Counter-Reformation Europe. Edited by Sherrin Marshall. Bloomington: Indiana University Press, pp. 8-28.

Wiesner-Hanks, Merry. 2000. Women and Gender in Early Modern Europe. Cambridge: Cambridge University Press. Wilson, Derek. 2016. Mrs Luther and Her Sisters: Women in the Reformation. Oxford: Lion Hudson PLC.

Yost, John. 1997. Changing Attitudes Towards Married Life in Civic and Christian Humanism. Occasional Papers for the American Society for Reformation Research 1: 151-66.

(C) 2020 by the author. Licensee MDPI, Basel, Switzerland. This article is an open access article distributed under the terms and conditions of the Creative Commons Attribution (CC BY) license (http://creativecommons.org/licenses/by/4.0/). 